\title{
Level of Determinants Impact on Buyer's Purchasing Intention in Motor Liability Insurance: Case of Vietnam
}

\author{
Hoang Van Anh ${ }^{1} \quad$ Mai To Linh ${ }^{1 *} \quad$ Nguyen Phuong Linh ${ }^{1} \quad$ Vu Hong Anh ${ }^{1} \quad$ Ngo Minh Phuong ${ }^{2}$ \\ 1.School of Advanced Education Programs, National Economics University, 207 Giai Phong Road, Hanoi \\ 10000-14000, Vietnam \\ 2.Faculty of Investment, National Economics University, 207 Giai Phong Road, Hanoi 10000-14000, Vietnam
}

\begin{abstract}
Motor liability insurance has been included in the compulsory insurance category that each vehicle owner of every type of motor vehicle must participate in in Vietnam. However, in fact, the participation in this type of insurance is not popular and not strictly managed. This paper presents an approach to modeling and analyzing the possible determinants that may affect the intention to buy motor liability insurance for motor vehicle owners in the North of Vietnam. The target audience of this study is motorcycle owners. Based on the theories of buying intention, buying behavior and the specific characteristics of this insurance, this study has proposed a model with 4 factors influencing intention to participate in the insurance: Attitudes towards risk and insurance, subjective standards, Insurance Perceptions, and Product Accessibility. Taken together, these factors model a consumer's tendency toward insurance intentions for motorbike owners. The results show that all of the above factors have influence on the intention of motorcycle owners to participate in insurance.
\end{abstract}

Keywords: Motor liability insurance, Buying intention, Purchase decision

DOI: $10.7176 / \mathrm{EJBM} / 13-8-11$

Publication date: April $30^{\text {th }} 2021$

\section{Introduction}

The high rise in demand for human transportation leads to substantial demands on the number of motor vehicles in the country, which poses many risks for not only the vehicle owners but also other parties. According to the report of the National Traffic Safety Committee (2020), in the period from October 15, 2015 to October 14, 2020, there have been 94,024 traffic accidents nationwide, killing 39,917 people and 77,477 wounded people. Therefore, it is necessary to establish a common fund to compensate and ensure the damage to third party health and property caused by an accident for which drivers and/or owners of the car. That is the reason why Motor Liability Insurance was created.

Motor Liability Insurance is a financial protection system built to prevent any grievance that third parties could face, due to the lack of solvency of the first party who caused bodily injury or property damage following any event related to a car accident. With such practical and humane meanings, up to now, compulsory Motor Liability Insurance of motor vehicle owners has achieved many positive results.

According to recent statistics of the Insurance Administration and Supervision Department (Ministry of Finance), in 2019 alone, total compulsory insurance premium revenue is estimated at 3,590 billion VND, of which cars alone are 2,825 billion VND 765 billion for motorbikes. However, Motor Liability Insurance still has shortcomings and problems in both policy and organization and implementation. Because of the compulsion of the law, most motorbike owners participate in the insurance only to have valid documents. The insured parties do not pay attention to the benefits of this type of insurance as well as the benefits enjoyed when the insurance events occur. Furthermore, according to the Department of Insurance Supervision and Administration, the motor insurance participation rate is still low, reaching about 30\% for motorbikes (out of a total of nearly 60 million motorbikes), and the participation rate of insurance is still low. up to $90 \%$ for cars (out of a total of over 3 million cars).

In fact, the participation in Motor Liability Insurance impacts significantly on the health of the insurance companies and the financial industry. The provision of compulsory insurance products for motor vehicle owners contributes to the sustainable development and efficiency of business operations

Combining with the real situation mentioned above, our paper analyzes the perceptions which lead to the Motor Liability Insurance purchasing intention which can be named as "Level of Determinants Impact on Buyer's Purchasing Intention in Motor Liability Insurance: Case of Vietnam”.

\section{Literature Review}

In Vietnam, the policy regarding motor vehicle owner's motor liability insurance is implemented in accordance with Decree No. 03/2021: "The liability insurance is compulsory, each motor vehicle owner must have at least one motor liability insurance". Other than that, motor vehicle owners can participate in voluntary insurance contracts through direct channels; insurance agents; banking-insurance affiliate channels, online or any other forms under the law. 
Since insurance is a financial product, the intention to participate in insurance also has its own distinct characteristics. Firstly, insurance is an intangible service. Secondly, consumers' demand depends on financial needs that arise in the event of a risk. Consumers have no need to use them but need to protect and overcome risks in the most effective way. Thirdly, unlike other products, while having to pay a certain amount for the product, consumers receive use-value only when they are at risk.

The study "Motor third party liability insurance - Polish market in connections to European trends" by Ilona Kwiecień and Ewa Poprawska, published in 2012 has mentioned that in European countries, motor vehicle insurance is a type of insurance that is continuously being invested in and developed since it is also the dominant product of non-life insurance companies. In the middle and eastern countries, this type of insurance accounts for about a quarter of the total. In the article, the author has analyzed the factors affecting the development of this insurance. They focus on the number of accidents and road safety, the frequency rate and number of claims, macroeconomics problems and other legal factors. In addition, financial issues such as insurance premiums and margins are also mentioned.

The study "Development of Motor Third Party Liability Insurance Market in terms of changing regulation" by Boban Tomeski in May 2012 has stated that motor owner's insurance for third parties is one of the most important areas in the business of developed and developing countries. The article focuses on presenting and analyzing the regulatory changes in the motor vehicle owner's personal insurance market for third parties with the main focus of implementing the laws of the European Union the Republic of Macedonia and regarding the price of this insurance. In this article, the authors mention the advantages and disadvantages resulting from the transition from a state-run system to a free tax regime for motor vehicle owners' insurance for a third person. In addition, the development of motor vehicle owner's insurance for third parties is also mentioned, but not mention its impact on the customer's decision to buy and use this type of product.

In 2011, Petrolimex Joint Stock Insurance Company proposed the current situation as well as the recommended solutions to this problem in the study of "Motor vehicle owner civil liability insurance operations for the third person". In 2012, the company continued to inherit and implement works related to the current situation and some recommendations to improve the efficiency of third-party liability insurance of motor vehicle owners in Vietnam.

In 2014, at the Vietnam Young Science Talent Award, this problem was the main topic of the research team in National Economics University's Faculty of Insurance: Nguyen Xuan Tiep, Nguyen Thi Phuong Anh, Nguyen Thi Mai Huong, Ngo Hai Son, Phan Thi Minh Tam. The topic of the project is "Research on the behavior of motor vehicle owners in the group of 18-22 years old to use insurance products for third-parties". The authors have exploited the factors affecting the use of insurance products of motor vehicle owners for third parties. In 2015, the National Economics University also issued an Overview Document on motor vehicle owner's liability insurance for third parties to clarify as well as inform about the features and properties of the product.

In most research, buying intention is defined as a customer's thoughts and willingness to buy a product, and/or continue using the product. This demonstrates consumers' motivation to make an effort before taking a behavior. Unlike buying behavior, buying intention is used to predict buying behavior, preceded by buying behavior (Engel, 2003). While both are influenced by objective and subjective factors, buying intention is always formed before a consumer takes a particular behavior. Purchasing intention is assessed as a human action guided by the consideration of three factors: Attitude towards behavior, Subjective Norms, and Perceived behavioral control (Ajzen, 2002).

According to the Theory of Planned Behavior (Ajzen \& Fishbein, 1985), the factors will directly affect buying intent, thereby forming buying behavior. Therefore, the research team chooses to analyze the factors that affect consumer intentions. Most studies have shown that: in addition to the common influencing factors, buying behavior is also influenced by point-of-sale situations for certain goods (Nguyen Ngoc Quang, 2015).

Theory of Reasoned Action (Fishbein and Ajzen, 1975) is a psychological theory that proves human behavioral intention is formed under their will and control, in other words, the individual can decide whether to act or not. Behavioral intention (representing actual behavior) is a function of attitude towards behavior and subjective norms.

The Theory of Planned Behavior first appeared in Ajzen's study in 1991, which is a successor and development of the Theory of Reasoned Action (TRA). From the TRA theory (Fishbein and Ajzen, 1975) Ajzen and Fishbein's TPB has been improved to overcome the limitations of the interpretation of uncontrolled behaviors. In addition to the factor "Attitude towards behavior" and "Subjective Norms", Ajzen also added a third factor, Perceived Behavior Control.

According to the TRA theory of rational action of Ajzen \& Fishbein (1975), Attitude is one of the most important factors in determining behavioral intention and referring to how a person perceives a particular behavior.

There are many studies that have taken Attitude as one of the factors influencing consumers' intention to buy in general and to buy insurance specifically. For example, Attitude has appeared as one of the determinants in "Factors affecting farmers' intention to participate in voluntary social insurance: The case in Phu Yen province" 
(Hoang Thu Thuy, Bui Hoang Minh Thu, 2018) or in "A number of factors affecting the interest in voluntary social insurance of small traders in Nghe An province" (Nguyen Xuan Cuong, Nguyen Xuan Tho, Ho Huy Tuu, 2013).

In other types of voluntary or compulsory insurance, the insurance participation rate of Vietnam is also much lower than that of other countries, the reason is that Vietnamese people do not like to talk about risks and they show a negative attitude whenever the topic of "Insurance" arises. There is still a lot of aversion to insurance companies; that is because they have been scammed or dissatisfied with the services of the insurance company. Maybe this is one of the reasons why Vietnamese people are not interested in personal insurance for vehicles, with the participation rate of only about 30\% (Ha Noi Moi newspaper, 2019) after more than 10 years of implementation.

Subjective Norms are defined as the perceptions of an individual, which were influenced by their important references to whether the behavior should or should not be done (Fishbein \& Ajzen, 1975). This has appeared in several pieces of research as a determinant. "Analysis of factors affecting the life insurance needs of people in Hanoi city" by Vu Thi Tram Anh et al (2020); "Factors affecting personal acts of digital copyright infringement in Vietnam" - Pham Quoc Trung, Dang Nhut Minh (2017); Nguyen Xuan Cuong, Nguyen Xuan Tho and Ho Huy Tuu (2014), "Some factors affecting the interest in participation in voluntary social insurance of small traders in Nghe An province" on Journal of Science VNU, Economics and Business have also used this factor to test the hypothesis whether subjective standards influence consumer buying decisions.

According to Alan Saks and Gary Johns (2005), there are three main determinants that influence perception. The first is the perception person. The second is the cognitive goal. The third is the situation. People can have different perceptions of the same object, product or service. This difference is due to the effect of three laws in cognitive processes: selective attention, distortion, and depiction. Following the study by Cox \& Rich (1964), Bauer (1960), Jacoby \& Kaplan (1972) and Cumningham (1967) and the model of the studies 'Gender differences in the perceived risk' of buying online and the effects of receiving a site recommendation " by Garbarino \& Strahilevitz (2004), our research team found a similarity that if users are more aware of the effectiveness of insurance, the more likely insurance consumers will have the intention to buy the insurance. As a result, the research team model has included this factor to test the accuracy for the case in Vietnam.

Demographics are the research of the studied population's data based on personal factors and related data such as income, occupation, age, and gender. Using demographics to divide the population into subgroups helps researchers determine the size of a potential market. The sizes of these groups still change over time due to economic, cultural, and political circumstances.

\section{Methodology}

Data: This study used survey questionnaires, both direct and indirect questionnaires with statistics analysis. The study sample are those who have not, have been, and are using motor liability insurance. The research team has collected 551 questionnaires with 22 direct and 529 online questionnaires, of which the online questionnaire in the question which filtered the subjects who do not use motorbikes and who are not answered is 31 votes. The remaining 520 valid votes were put to use in the next analysis. In the sample, there were 230 people aged 21 to 30 , 219 people aged under 21,11 people aged 31 to 40, 20 people aged 41 to 50 , and 10 people aged 51 to 60 .

Method: The research is done according to a process consisting of 5 main stages: research topic and theoretical review; collect documents; data collection; preliminary research; analyze the data and finally present the research results as well as the recommendations and suggestions of our team. In the data analysis process, we used statistical methods and SPSS software to run the data. The statistical methods used include: descriptive statistics (to briefly describe the sample), quantitative analysis, t-test, ANOVA, and correlation methods (to eliminate nonconforming variables, measure the confidence level, and measure the relevance of the factors in the proposed model).

After consulting other studies, we propose the following research model:

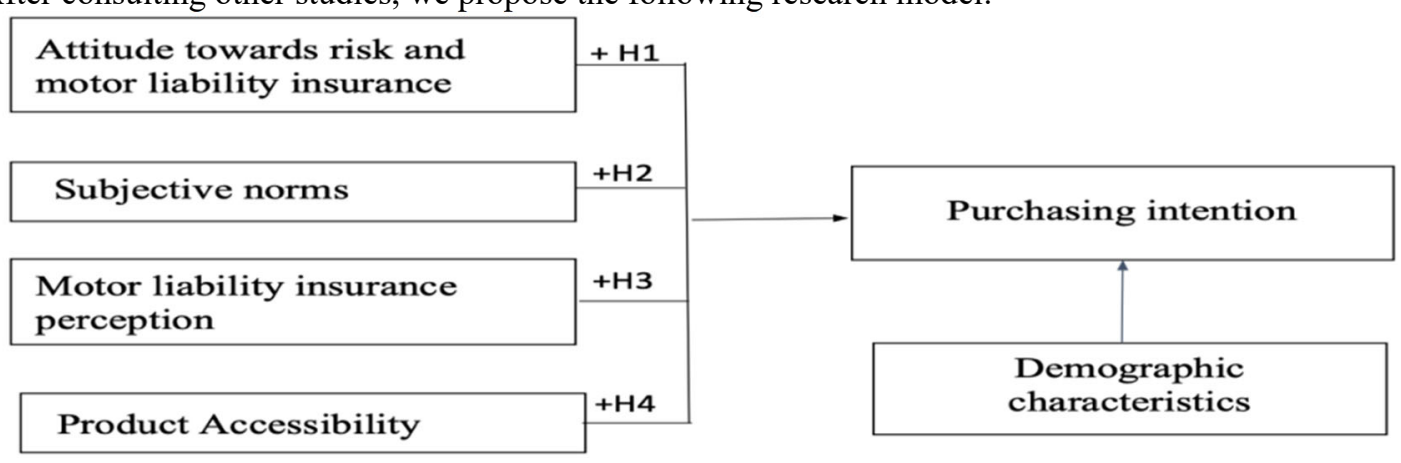

Model application of TRA and TPB models of Fishbein \& Ajzen

Figure: Proposed Model of the Research "Level of Determinants Impact on Buyer's Purchasing Intention in Motor Liability Insurance: Case of Vietnam" 
The research team considered that the factors that influence the intention to buy motor liability insurance in the North of Vietnam include: Attitude towards risk and motor liability insurance, Subjective norms, Motor liability insurance perception, and Product accessibility. All of these determinants show a positive effect on the purchasing intention. In addition, the research team also want to examine the influence of control variables such as age, sex, education level, income and living environment.

\section{Research hypothesis:}

\section{- $\quad$ Attitude towards risk and motor liability insurance}

According to the TRA theory of rational action of Ajzen \& Fishbein (1975), attitude is one of the most important factors in determining behavioral intent and referring to how a person perceives towards a particular behavior. In the study of Lin liyue \& Zhu Yu (2006); Min-sun Horng \& Yung Wang Chang (2007), the author pointed out: "If the consumer is afraid of the risks in traffic and believe that the auto insurance is useful to them, then According to the logic of TRA and TPB theory, consumers will increase their intention to buy car insurance ". The research team also referred to the study "Factors affecting the intention of farmers to participate in voluntary social insurance: The case in Phu Yen province" Hoang Thu Thuy, Bui Hoang Minh Thu (2018) also indicated that attitude had a strong influence on the farmers' decision to participate in insurance. Therefore, the Research team wants to test the hypothesis

H1: Attitude towards risk and motor liability insurance has a positive impact on the Purchase intention.

\section{- Subjective norms}

Subjective norms are defined as perceptions of an individual, with their important references to whether the behavior should or should not be done (Fishbein \& Ajzen, 1975). Subjective norms can be measured through the relevant people to the consumer, determined by the standard beliefs for the expected performance of the behavior and the personal motivation to comply with that expectation. (Fishbein \& Ajzen, 1975, p. 16).

If a consumer is influenced by the environment to accept and support to participate in Motor Liability Insurance, then they will be more likely to participate in Motor Liability Insurance than if he or she is affected by the environment that does not accept Motor Liability Insurance. Applying the Theory of Reasonable Action (TRA) of Martin Fishbein and Icek Ajzen, and also refer to the Research "Analysis of factors affecting the life insurance needs of people in Hanoi city."- Vu Thi Tram Anh et al (2020); "Factors affecting personal acts of digital copyright infringement in Vietnam" - Pham Quoc Trung, Dang Nhut Minh (2017); Nguyen Xuan Cuong, Nguyen Xuan Tho and Ho Huy Tuu (2014), Some factors affecting the interest in participation in voluntary social insurance of small traders in Nghe An province, Journal of Science VNU, Economics and Business, 30 (1), 36-45. With the scale: The influential people (friends, family) support the participation in Motor Liability Insurance, many people around to participate in Motor Liability Insurance, information sources mention that participating in Motor Liability Insurance is necessary, the research team tested the hypothesis:

\section{H2: Subjective norms have a positive impact on the Purchase intention.}

\section{- Motor liability insurance perception}

There are 3 main factors that influence perception including the perceiver, the perceived target, and the situation. Through two studies by Alan Saks and Gary Johns (2005) and Schiffman \& Wisenblit (2015), perception of a perceived product will create an image of the product in the consumer's subconscious. affect the process of buying intentions of consumers. In perception, there have been a number of research papers that have been successful in clarifying and demonstrating the relationship between product perceptions and payer buying intentions. In the study "The impact of motivation, perceptions and attitudes on consumers Buying decisions: A case study by Surabaya and the Jakarta Society on Carl's Junior", author Steffi Gunawan used Schiffman \& Wisenblit's study (2015) and Hawkins \& Mothersbaugh (2013) as a basis for analyzing the effect of perception on purchasing decisions or buying intention, thereby generalizing that customer perceptions of products include three main influencing factors which are product position in the market, quality perception and risk perception. Meanwhile, Ivan Ruso's research on "The impact of consumer perception on bio-waste products in a closed supply chain" demonstrates that past buying experience has influence in the same direction with the intention to purchase the product. In addition, the awareness factor is also affected by the peace of mind of customers when dealing with products and services. Saleeby (2008), Kassim and Asiah Abdullah (2010) and Rodrigues (2013) studied the relationship that exists between service quality and customer purchasing intention, and found that assurance is highly relevant to purchasing intention. From these analyzes, the team tested the hypothesis:

H3: Motor liability insurance perception has a positive impact on the Purchase intention.

\section{Product accessibility}

Product accessibility was mentioned in the 1981 study by Penchansky Roy D.B.A and Thomas, J William with the topic of "Customer motivation to maintain using products and services". In addition, the 1995 study by Neeli Bendapudi and Leonard L. Berry also showed that if the product is widely available and suitable for all customers of all ages, income status, etc, then the consumers will be more likely to purchase and continue to use the insurance products. The study of "Factors affecting the decision to buy voluntary health insurance of people in Can Tho" in 2017 by Le Canh Bich Tho et al., the study of "Intention to buy voluntary health insurance of people in Trang 
Bom District, Dong Nai Province" in 2018 by author Nguyen Thi Xuan Huong et al, the study of "Life Insurance and Household Consumption" in 2012 by Hong, Jay H., Rios-Rull and Jose-Victor; Liebenberg et al's 2012 study on the use of life insurance, the study on "Financial performance of life insurance companies in Ghana" in 2013 by Akotey et al have all shown the significant level of this determinants to the consumer's intentions to start using or continue to use the insurance product. These studies have also demonstrated that this factor is likely to be affected by the level and way of communication of the product and consumer knowledge about the product. This is why our research team would test the hypothesis:

H4: Product accessibility has a positive impact on the Purchase intention.

\section{Analytical Results}

The research team decided to evaluate the reliability of the scale through Cronbach's Alpha coefficients for each group of observed variables of different factors. Evaluate the reliability to eliminate garbage variables (variables we think can measure a concept or hypothesis but in fact it has no effect on other metrics).

Through Cronbach Alpha analysis, if the observed variable has the correlation coefficient between the variable and the total $<0.3$, it will be excluded from the scale. Each component of research concepts (influencing factors) must have Cronbach's Alpha coefficient $>0.6$.

Table 1: Cronback's Alpha analysis

\begin{tabular}{|c|c|c|c|c|}
\hline & $\begin{array}{l}\text { Scale Mean if Item } \\
\text { Deleted }\end{array}$ & $\begin{array}{l}\text { Scale Variance if } \\
\text { Item Deleted }\end{array}$ & $\begin{array}{l}\text { Corrected } \\
\text { Item-Total } \\
\text { Correlation }\end{array}$ & $\begin{array}{l}\text { Cronbach's Alpha if } \\
\text { Item Deleted }\end{array}$ \\
\hline \multicolumn{5}{|c|}{ 1.Attitude towards risk and motor liability insurance: $\alpha=0.832$} \\
\hline A1 & 5.24 & 11.203 & 0.566 & 0.816 \\
\hline A2 & 15.28 & 10.500 & 0.683 & 0.783 \\
\hline A3 & 15.21 & 10.378 & 0.711 & 0.775 \\
\hline A4 & 15.08 & 11.326 & 0.574 & 0.814 \\
\hline A5 & 15.27 & 10.509 & 0.623 & 0.801 \\
\hline \multicolumn{5}{|c|}{ 2. Subjective norms: $\alpha=0.848$} \\
\hline S1 & 7.64 & 2.042 & 0.711 & 0.794 \\
\hline S2 & 7.65 & 2.062 & 0.725 & 0.782 \\
\hline S3 & 7.62 & 1.979 & 0.715 & 0.791 \\
\hline \multicolumn{5}{|c|}{ 3. Motor liability insurance perception: $\alpha=0.854$} \\
\hline P1 & 14.87 & 6.686 & 0.706 & 0.814 \\
\hline $\mathrm{P} 2$ & 14.86 & 6.785 & 0.678 & 0.821 \\
\hline $\mathrm{P} 3$ & 14.89 & 6.734 & 0.672 & 0.823 \\
\hline P4 & 14.83 & 6.659 & 0.706 & 0.814 \\
\hline P5 & 14.99 & 7.069 & 0.576 & 0.848 \\
\hline \multicolumn{5}{|c|}{ 4. Product accessibility: $\alpha=0.803$} \\
\hline PA1 & 11.44 & 5.468 & 0.568 & 0.780 \\
\hline PA2 & 11.14 & 5.753 & 0.646 & 0.742 \\
\hline PA3 & 11.33 & 5.399 & 0.614 & 0.755 \\
\hline PA4 & 11.23 & 5.635 & 0.652 & 0.737 \\
\hline
\end{tabular}

The analysis results of Cronbach's Alpha reliability of the scales are shown in Table 1, showing that all measurement concepts reach Cronbach Alpha coefficients of 0.60 or more, specifically: Cronbach's alpha coefficient varies from 0.803 to 0.990 ; therefore, it is not necessary to remove the variable to improve the Cronbach Alpha coefficient. In addition, the observed variables have variable correlation coefficients - total from 0.30 or more. Thus, the scale of factors affecting the intent to use all reaches the required reliability.

Before performing regression analysis, examine Pearson's correlation coefficient to quantify the rigor of linear relationships between the independent and dependent variables, as well as between the dependent variables.

Correlation analysis results are presented in the table 1 
Table 2: Correlation analysis

\begin{tabular}{|c|c|c|c|c|c|c|}
\hline \multicolumn{7}{|c|}{ Correlations } \\
\hline & & $\begin{array}{l}\text { Attitude } \\
\text { towards } \\
\text { risk and } \\
\text { motor } \\
\text { liability } \\
\text { insurance }\end{array}$ & $\begin{array}{l}\text { Subjective } \\
\text { norms }\end{array}$ & Perception & $\begin{array}{l}\text { Product } \\
\text { Accessibility }\end{array}$ & Intention \\
\hline \multirow{3}{*}{$\begin{array}{l}\text { Attitude } \\
\text { towards risk } \\
\text { and motor } \\
\text { liability } \\
\text { insurance }\end{array}$} & $\begin{array}{l}\text { Pearson } \\
\text { Correlation }\end{array}$ & 1 & $.279^{* *}$ & $.244^{* *}$ & $.302^{* *}$ & $.473^{* *}$ \\
\hline & $\begin{array}{l}\text { Sig. } \\
\text { tailed) }\end{array}$ & & .000 & .000 & .000 & .000 \\
\hline & $\mathrm{N}$ & 520 & 520 & 520 & 520 & 520 \\
\hline \multirow[t]{3}{*}{$\begin{array}{l}\text { Subjective } \\
\text { norms }\end{array}$} & $\begin{array}{l}\text { Pearson } \\
\text { Correlation }\end{array}$ & $.279^{* *}$ & 1 & $.346^{* *}$ & $.347^{* *}$ & $.439^{* *}$ \\
\hline & $\begin{array}{l}\text { Sig. } \\
\text { (2-tailed) }\end{array}$ & .000 & & .000 & .000 & .000 \\
\hline & $\mathrm{N}$ & 520 & 520 & 520 & 520 & 520 \\
\hline \multirow{3}{*}{$\begin{array}{l}\text { Motor } \\
\text { liability } \\
\text { insurance } \\
\text { Perception }\end{array}$} & $\begin{array}{l}\text { Pearson } \\
\text { Correlation }\end{array}$ & $.244^{* *}$ & $.346^{* *}$ & 1 & $.379^{* *}$ & $.561^{* *}$ \\
\hline & $\begin{array}{l}\text { Sig. } \\
\text { (2-tailed) }\end{array}$ & .000 & .000 & & .000 & .000 \\
\hline & $\mathrm{N}$ & 520 & 520 & 520 & 520 & 520 \\
\hline \multirow[t]{3}{*}{$\begin{array}{l}\text { Product } \\
\text { Accessibility }\end{array}$} & $\begin{array}{l}\text { Pearson } \\
\text { Correlation }\end{array}$ & $.302^{* *}$ & $.347^{* *}$ & $.379^{* *}$ & 1 & $.543^{* *}$ \\
\hline & $\begin{array}{l}\text { Sig. } \\
\text { (2-tailed) }\end{array}$ & .000 & .000 & .000 & & .000 \\
\hline & $\mathrm{N}$ & 520 & 520 & 520 & 520 & 520 \\
\hline \multirow[t]{3}{*}{$\begin{array}{l}\text { Purchasing } \\
\text { intention }\end{array}$} & $\begin{array}{l}\text { Pearson } \\
\text { Correlation } \\
\end{array}$ & $.473^{* *}$ & $.439^{* *}$ & $.561^{* *}$ & $.543^{* *}$ & 1 \\
\hline & $\begin{array}{l}\text { Sig. } \\
\text { (2-tailed) }\end{array}$ & .000 & .000 & .000 & .000 & \\
\hline & $\mathrm{N}$ & 520 & 520 & 520 & 520 & 520 \\
\hline
\end{tabular}

Source: Analysis results of the research

From the results of Table 2, we see that the dependent variable "purchase intention" and independent variables (1) subjective norms, (2) motor liability insurance perception, (3) product acc are significantly correlated, statistical significance at 5\% (sig. $<5 \%)$. The independent variables are correlated in the same direction with the dependent variable (correlation coefficient is greater than 0.4 and less than 0.6 ). To test which independent variables actually influence buying intent and how these factors affect buying intent, the study continues to run multivariate regression.

Table 3: Descriptive statistics

\begin{tabular}{|l|l|l|l|l|l|}
\hline Descriptive Statistics & $\mathrm{N}$ & Minimum & Maximum & Mean & Std. Deviation \\
\hline Purchasing intention & 520 & 1 & 5 & 3.80 & 0.765 \\
\hline $\begin{array}{l}\text { Attitude towards risk and motor } \\
\text { liability insurance }\end{array}$ & 520 & 1.00 & 5.00 & 3.8038 & 0.80422 \\
\hline Subjective norms liability insurance & 520 & 1.20 & 5.00 & 3.7219 & 0.63971 \\
\hline $\begin{array}{l}\text { Motor } \\
\text { Perception }\end{array}$ & 520 & 1.25 & 5.00 & 3.7606 & 0.76164 \\
\hline Product Accessibility & 520 & & & & \\
\hline Valid N (listwise) & 520 & 1.67 & 5.00 & 3.8179 & 0.68643 \\
\hline
\end{tabular}

Source: Analysis results of the research

Table 3 shows the descriptive statistics result. All variables have average (Mean) greater than 3 , subjective standards variable has the highest mean (3.8038) while Perception Application variable has the lowest mean (3.7219). The lowest standard deviation is the Perception variable at 0.63971 and the highest one is Attitude Application at 0.80422 . From these results, it can be said that questionnaires must have received many "agree" or "very agree" assessments from respondents. 
Table 4: Model Summary

\begin{tabular}{|l|c|l|l|l|c|}
\hline \multicolumn{6}{|c|}{ Model Summary ${ }^{\mathrm{b}}$} \\
\hline Model & $\mathrm{R}$ & R Square & Adjusted R Square & $\begin{array}{l}\text { Std. Error of the } \\
\text { Estimate }\end{array}$ & $\begin{array}{l}\text { Durbin- } \\
\text { Watson }\end{array}$ \\
\hline 1 & $.730^{\mathrm{a}}$ & .533 & .529 & .525 & 1.711 \\
\hline
\end{tabular}

According to the estimated model result, $\mathrm{R}$ Square $=0.533$, which means independent variables in the model could explain $53.5 \%$ of the overall level. That the estimated result is greater than $50 \%$ would be accepted in a model.

Table 5: Coefficient of regression model of The Factors influencing Motorbike Third Party Liability Insurance purchasing intention

\begin{tabular}{|c|c|c|c|c|c|c|c|c|}
\hline \multicolumn{9}{|c|}{ Coefficients ${ }^{\mathrm{a}}$} \\
\hline \multirow{2}{*}{\multicolumn{2}{|c|}{ Model }} & \multicolumn{2}{|c|}{$\begin{array}{l}\text { Unstandardized } \\
\text { Coefficients }\end{array}$} & \multirow{2}{*}{$\begin{array}{l}\begin{array}{l}\text { Standardized } \\
\text { Coefficients }\end{array} \\
\text { Beta }\end{array}$} & \multirow[t]{2}{*}{$\mathrm{t}$} & \multirow[t]{2}{*}{ Sig. } & \multicolumn{2}{|c|}{$\begin{array}{l}\text { Collinearity } \\
\text { Statistics }\end{array}$} \\
\hline & & B & $\begin{array}{l}\text { Std. } \\
\text { Error }\end{array}$ & & & & Tolerance & VIF \\
\hline \multirow[t]{5}{*}{1} & (Constant) & -.363 & .177 & & $-\overline{2.056}$ & .040 & & \\
\hline & $\begin{array}{lr}\text { Attitude } & \\
\text { towards } & \text { risk } \\
\text { and } & \text { motor } \\
\text { liability } & \\
\text { insurance } & \\
\end{array}$ & .250 & .031 & .263 & 8.128 & .000 & .865 & 1.156 \\
\hline & $\begin{array}{l}\text { Subjective } \\
\text { norms }\end{array}$ & .168 & .037 & .150 & 4.473 & .000 & .803 & 1.245 \\
\hline & $\begin{array}{l}\text { Motor liability } \\
\text { insurance } \\
\text { Perception }\end{array}$ & .403 & .040 & .337 & 9.974 & .000 & .795 & 1.258 \\
\hline & $\begin{array}{l}\text { Product } \\
\text { Accessibility }\end{array}$ & .284 & .034 & .283 & 8.270 & .000 & .774 & 1.292 \\
\hline
\end{tabular}

Source: Analysis results of the research

According to Table 5. Regression analysis, the statistical results show that the normalized regression coefficients of the regression equation are different from 0 and Sig. $<0.05$ means that there are 4 independent variables: subjective norms, attitudes towards risk and motor liability insurance, Perception, and Product Accessibility are all involved in the influence of buying intent of customers.

According to Nguyen Dinh Tho (2011), if we use non-standardized regression coefficients, it is difficult to compare the impact levels of the independent variables because the scales of them are often different. Therefore, we must use normalized regression weights for more precise comparisons. Comparing the value of the normalized coefficients in the Beta column shows that: Motor liability insurance perception is the most important factor $(\beta=$ 0.337 and sig. $=0.000)$, then Product Accessibility $(\beta=0.283$ and sig. $=0.000)$, and the lowest is the Subjective norms factor $(\beta=0.150$ and sig. $=0.000)$. From these results, it can be said that all determinants mentioned above have a positive impact on Purchasing intention.

\section{Discussion and Conclusion}

Our study generates results with regard to the impact of factors affecting motorbike owners' intention to join the Motor liability insurance. In the article we provide information and definitions about this type of insurance as well as the theory related to consumer purchase intention and consumer purchase behavior theory such as TRA, TPB. We then examined the influence of these factors on consumers' intention to buy motor liability insurance based on 520 survey applications. Finally, we offer recommendations to improve the percentage of people participating in buying this insurance.

From data analysis, it can be seen that other factors have a positive effect on the customer's intention to buy the motor liability insurance. The factor "Motor liability insurance Perception" has the strongest impact, then "Product Accessibility", "Attitude towards risk and motor liability insurance" and finally "Subjective norms".

Nowadays, when your time and money play an important role in life, when participants feel the control of the two factors above, they are more willing to join and accept insurance. Through the evaluation of the independent variables, perceptions of the benefits of insurance will attract and influence purchasing decisions rather than perceptions of product mandatory. 
Additionally, through the survey, the research team also found that finding information and participating in insurance easily will have a very strong impact on the buying intention of customers. Therefore, businesses need to focus on improving propaganda to increase the brand identity of the company and increase the belief in the product.

In fact, when consumers have a positive attitude towards the motor liability insurance, especially through the fact that consumers want to find information about it and start considering it as the responsibility of each vehicle owner. Moreover, the higher level of risk aversion in traffic such as the concern of the ability to pay a third person if an accident occurs, the more intentions of joining and reinsuring the motor liability insurance of motor's owners. These variables were also clearly demonstrated in the research group survey with their correlation to buying intent: $82 \%, 79 \%$ and $78 \%$, respectively. Participating in this insurance will help customers free themselves from thinking about social responsibility and worrying about risks so they can be more confident in traffic.

Finally, the number of people choosing the plan "totally agree"; "agree" and "normal" in the observed variables in the subject group of variables are dominant, at the same time, the rate of this variant in the subjective standard is also higher than the other groups of variables. This shows that most of the survey participants think that people around have influence on their decision to buy the motor liability insurance, but the level of influence is not high and there is no difference between target groups.

Subjective norms with scales "Information sources mentioned that It is necessary to participate in Motor Liability Insurance" was rated the most by people, followed by "Influencers (friends, family) support the participation of Motor Liability Insurance", and the last is "Many people around participate in Motor Liability Insurance", be positive contributor to the intention of participating in Motor Liability Insurance, the Research Team continues to make recommendations to contribute to the insurers about propaganda, to enhance the impact of subjective norms on the intention of people to participate.

\section{Limitations and Further Study}

Although there are positive contributions from the analyzed results, the study "Level of Determinants Impact on Buyer's Purchasing Intention in Motor Liability Insurance: Case of Vietnam" still has certain limitations:

First, study time and resources are limited. The study was carried out during the Covid-19 epidemic break period, especially the social gap period coincided with the time the research team collected data, so the number of votes was still limited. quality and quality. Because the main form of voting is online, the research team cannot control who receives the votes, leading to the phenomenon of unsubstantiated votes, a lot of rubbish votes. Secondly, there is a difference in age, education, ... in the survey results, which affects more or less the research results. Thirdly, the research team is unable to deeply exploit the professional issues of insurance companies and state management agencies, so the research is still subjective with little practical significance.

If there are opportunities in the future, the research team will expand the scope of the study, increase the size of observations and direct investigations in the insurance companies more carefully to study and propose convincing and efficient solutions.

\section{References}

1. Ministry of Finance (2016), Circular No. 22/2016 / TT-BTC, Rules, terms, fee schedule and compulsory insurance liability level for motor vehicle owners' civil liability, 16 / February 2016, Hanoi.

2. Government (2021), Decree No. 03/2021 / ND-CP, Decree on compulsory insurance of civil liability of motor vehicle owners, 15/01/2021, Hanoi.

3. Government (2020), Notice No. 396 / TB-VPCP, Conclusion of Standing Deputy Prime Minister Truong Hoa Binh at the Conference on reviewing 05 years of emulation movement to ensure traffic order and safety the 2016-2020 period; Traffic safety year 2020 and key tasks for the period 2021-2025, December 15, 2020, Hanoi.

4. Vietnam Registry Department (2019), Synthesize national traffic data, accessed February 21, 2019, from: http://www.vr.org.vn/thong-ke/Pages /tong-hop-so-lieu-phuong-tien-giao-thong-trong-ca-nuoc.aspx

5. Traffic Police Department (2015), Motor vehicle owner's personal insurance for third person, last accessed on 22/02/2021 from http://www.csgt.vn/tintuc/4491/Bao-hiem-TNDS-cua-chu-xe-co-gioi-doi-voi-nguoi-thuba.html

6. Phi Long (2020), '5 years, nearly 40,000 people died in traffic accidents' last accessed on 22/02/2021, from https://vov.vn/xa-hoi/5-nam- liver-40000-people-chet-vi-nan-communication-826613.vov

7. Vu Thi Tram Anh et al (2020), Analysis of factors affecting the life insurance needs of people in Hanoi city, Journal of Science and Commerce, University of Commerce, 19 (145), 36-46.

8. Insurance Supervision and Administration Department (2019), Vietnam Insurance Market in 2019, accessed January 18, 2020 from: https: //www.mof.gov.vn/webcenter/portal/cqlgsbh/ $/ 1 / \mathrm{cm} 413066$ ? dDocName = MOFUCM180833 \& dID = 188991

9. Pham Quoc Trung and Dang Nhut Minh (2017), Factors affecting personal behavior of digital piracy in Vietnam, 
Science and Technology Development Journal, 20 (4), 80.

10. Nguyen Xuan Cuong, Nguyen Xuan Tho and Ho Huy Tuu (2014), Several factors affecting the interest in participation in voluntary social insurance of small traders in Nghe An province, The Journal Science, VNU, Economics and Business, 30 (1), 36- 45.

11. Dinh Thi Thanh Van, Nguyen Thi Hue (2016), 'Measuring and evaluating factors affecting personal financial understanding of students', State Bank of Vietnam, last accessed 16 March 2021, from $<$ https://www.sbv.gov.vn/webcenter/portal/en/menu/rm/apph/tcnh/tcnh_chitiet;jsessionid=T4k7dkjYGNEhS b XemJYnfF_LIB53LGMgs7hSiPaW69Z SBV245043 \& leftWidth $=20 \% 25 \&$ rightWidth $=0 \% 25 \&$ showFooter $=$ false $\&$ showHeader $=$ false \&_adf.ctrl-state $=5$ iyoc7k8y_9 \&_afrLoop $=$ $17836603339981297 \quad \# \% \quad$ 40\% $\quad 3 \mathrm{~F}$ afrLoop\% $\quad 3 \mathrm{D} 178366033399812$ th\% $\quad \% \quad$ 26showFooter\% $\%$ 3Dfalse $\%$ 26showHeader\%3Dfalse\% 26 adf.ctrl-state\% 3Dojc3tqkbh_4>

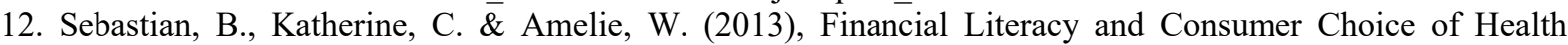 Insurance, last accessed 3 January 2021, from <https: //www.rand. org / content / dam / rand / pubs / working_papers / WR1000 / WR1013 / RAND_WR1013.pdf>

13. Nilufer, D., Erdem, K. (2015), 'The Role of Financial Literacy on the Development of Insurance Awareness', International Journal of Economics and Finance, 7 (8), 273-276, Last Accessed December 4, 2020, from $<10.5539$ / ijef.v7n8p272>

14. Kasule, S. (2011), Consumer attitudes, financial literacy and consumption of insurance in Kampala, Uganda, last accessed 6 December 2020, from <http://makir.mak.ac.ug/bitstream /handle/10570/2410/Kasule-MUBSMaster.pdf?sequence $=1 \&$ isAllowed $=\mathrm{y}>$

15. Ajzen, I., Fishbein, M. (1975), "Belief, Attitude, Intention, and Behavior".

16. Hoang Thu Thuy, Bui Hoang Minh Thu (2018), 'Factors affecting farmers' intention to participate in voluntary social insurance: The case in Phu Yen province, SCIENCE DEVELOPMENT TEAM \& TECHNOLOGY: ECONOMICS - LAW AND MANAGEMENT, VOLUME 2, NO.4, 2018

17. Phan Ngoc Luan (2016), "Analysis of factors affecting the intention to participate in the health insurance of households in the province of Phu Yen", master thesis.

18. Nguyen Anh Thu (2015), "Several factors affecting the intention to participate in voluntary social insurance of small traders in Dien Khanh district", master thesis.

19. Nguyen Xuan Cuong, Nguyen Xuan Tho, Ho Huy Tuu (2014), 'Some factors affecting the interest in participation in voluntary social insurance of small traders in Nghe An province', VNU Journal of Science, Economics and Business, Volume 30, Issue 1 (2014) 36-45

20. Le Van Huy, "A research model of factors influencing intention and decision to use ATM cards in Vietnam", Banking Journal, No. 4 (2006) 14

21. Linda Nga (2019), 'How attitudes affect human behavior ',October 30

22. Shrikant Krupasindhu Panigrahi, Noor Azlinna Azizan, Muhammad Waris Ali Khan (2018):'Investigating the Empirical Relationship Between Service Quality, Trust, Satisfaction, and Intention of Customers Purchasing Life Insurance Products', Indian Journal of Marketing.

23. Ivan Russo, Ilenia Confente, Daniele Scarpi \& Benjamin T. Hazen:'From trash to treasure: The impact of consumer perception of bio-waste products in closed-loop supply chains', Journal of Cleaner Production, Volume 218, 2019, Pages 966-974

24. Wang \& Hazen (2016), 'Consumer product knowledge and intention to purchase remanufactured products', International Journal of Production Economics.

25. Steffi Gunawan (2015), 'The Impact of Motivation, Perception and Attitude toward Consumer Purchasing Decision: A Study Case of Surabaya and Jakarta Society on Carl's Junior', Journal of iBuss Management Vol. 3, No. 2, (2015) 154-163

26. Schiffman \& Wisenblit (2015): Consumer Behavior, 11th Edition.

27. Alan Saks và Gary Johns (2005): Organizational Behaviour: Understanding and Managing Life at Work, 6th Edition.

28. Penchansky, R., \& Thomas, J. (1981). The Concept of Access: Definition and Relationship to Consumer Satisfaction. Medical Care, 19(2), 127-140. Retrieved April 21, 2021, from $<$ http://www.jstor.org/stable/3764310>

29. Neeli Bendapudi, Leonard L. Berry (1997) Customers' motivations for maintaining relationships with service providers, Journal of Retailing, ISSN 0022-4359, from <https://doi.org/10.1016/S0022-4359(97)90013-0. (https://www.sciencedirect.com/science/article/pii/S0022435997900130)>

30. Le Canh Bich Tho et al. (2016) 'Intention to buy voluntary health insurance of people in Trang Bom District, Dong Nai Province', Science Journal of Can Tho University. 48d: 20-25

31. Jay H. Hong \& Jose-Victor Rios-Rull, 2004. 'Life insurance and household consumption', Working Papers 04-10, Federal Reserve Bank of Philadelphia.

32. Oscar Akotey, J., Sackey, F.G., Amoah, L. and Frimpong Manso, R. (2013), "The financial performance of 
life insurance companies in Ghana", Journal of Risk Finance, Vol. 14 No. 3, pp. 286-302, from $<$ https://doi.org/10.1108/JRF-11-2012-0081>

33 . Nguyen Thi Xuan Huong et al. (2018), 'Intention to buy voluntary health insurance of people in Trang Bom District, Dong Nai Province'

34. I Kwiecień \& E Poprawska (2011), International Journal of Economics and Finance Studies 3 (2), 117-126. 